\title{
Profitability and Risk in Relation to Income Diversification of Vietnamese Commercial Banking System
}

\author{
VO XUAN VINH \\ University of Economics HCMC - vinhvx@ueh.edu.vn \\ TRAN THI PHUONG MAI \\ Asia Commercial Bank - phuongmai93nt@gmail.com
}

\section{ARTICLE INFO ABSTRACT}

Article history:

Received:

Jan. 272015

Received in revised form:

Aug. 202015

Accepted:

Mar. 252016
Employing a panel data set including 37 joint-stock commercial banks covering the period from 2006 to 2013, this paper investigates the impact of income diversification on bank risk and returns. Our results show that increased income diversification results in higher rates of bank returns. However, when risk is considered, the increased income diversification leads to lower risk-adjusted returns. Empirical evidence also shows that the income diversification is not beneficial to joint-stock commercial banks in Vietnam.

Keywords:

Income diversification, bank, returns, risk. 


\section{Introduction}

Since the early 2000s commercial banks in the world tend to diversify their activities, caused by competitive pressures or the profits from financial investment (DeYoung \& Roland, 2001). In Vietnam, due to a considerable increase in the number of commercial banks, there has been increasingly fierce competition between these banks, starting from 2006. In addition, the Vietnamese commercial banks have to perform against foreign ones, and the competition tends to be more intense when $100 \%$ foreign ownership is allowed in the national banking system. Furthermore, financial firms, with their significantly increasing number and size, in recent times have been connected to harsher competitiveness, which causes marginal revenue from traditional credit operations to have increasingly been shrinking.

The years of 2006-2007 saw a boom in stock market operations, and stock investment generated huge profits for market participants. Also during this period bank-affiliated firms operating in finance/stock domain contributed to capital and stock investments, bringing in higher noninterest income. High returns did seemingly enable banks to follow the strategy of income diversification as the proportion of their interest income fell.

However, the financial crisis, which lately led to several problems of contracted total demand of the economy, increased inventories, frozen real estate, stagnant production, and so on, has created numerous difficulties for Vietnamese enterprises, indirectly influenced bank performance, and particularly caused more nonperforming loans. In this period more loss provisions were required, which were sharply reducing banks' revenue from credit activities.

On the other hand, point losses in the stock market and reduction in market liquidity are other causes to increased risk posed to bank investments in nontraditional activities. In addition, the central bank increasingly tightened banks' risk management by means of specific regulations on risk prevention, enacted and modified to control banking activities. The level of loss provisions was also increased to prevent the effects of nonperforming loans on reducing banks' profits.

From another aspect the difficulties in lending activities, together with new regulations on control over credit activities, have forced banks to potentially diversify income sources so as to proceed with other activities in search of new opportunities. Noninterest income previously came from service charges from checks and trust or asset 
management services. Recently banking activities have expanded to include insurance, commercial investment, and others; hence, with the expansion of non-traditional activities, banks can realize their moves into a wider market segment in addition to higher earnings from more diversified sources. Nonetheless, changes in the economy in those past years have significantly impacted on the profitability and risk involving the banking sector.

A stream of research in the world has probed the impact of diversification of bank risk and profitability, the findings of which, however, are not consistent and perceived with great discrepancies (Gurbuz et al., 2013; Lee et al., 2014; Niu, 2012; Pennathur et al., 2012; Sanya \& Wolfe, 2011; Wagner, 2010). In fact, many of the commercial banks in Vietnam have implemented the strategy of income diversification over the past ten years despite fewer studies conducted to academically ponder the issue. As a contribution to the existing assessment of bank performance, accordingly, we consider the income diversification with its effects on the risk and profitability among Vietnamese commercial banks by addressing how the diversification affects the others.

\section{Literature review and hypotheses}

\subsection{Diversification and bank profitability}

Theoretically, one of the issues, which has been extensively studied but still reflects inconsistent outcomes, is whether diversification ever increases bank profitability in a stable and sustainable manner. Many researches showed that adopting an income diversification strategy leads to increase in bank profits. Smith et al. (2003) pointed out that more concentration on non-interest income generation will contribute to stabilizing the bank profitability. Chiorazzo et al. (2008) reported the diversification of non-interest income resulting in profit increase, which is supported by other studies with various datasets in different countries (Baele et al., 2007; Carlson, 2004; Elsas et al., 2010; Gurbuz et al., 2013; Landskroner et al., 2005).

Nevertheless, many empirical studies refuted the profit-related approach when banks attempt to diversify their income sources (DeYoung \& Roland, 2001; Stiroh, 2004a, 2006; Stiroh \& Rumble, 2006). Particularly, DeYoung and Roland (2001) analyzed the risk of losing customers during banks' involvement in activities that provide more income from charges than from the lending ones. Notwithstanding a great sensitivity between interest rates and recession, income from traditional activities remains stable 
over time as switching and information costs should cause it to be costly for both borrowers (customers) and lenders (banks), when loans are to be arranged with other banking institutions. For this reason the credit relationship between the customer and the bank reflects little changes. In another research Stiroh (2004a) highlighted a high correlation between interest income growth and non-interest income growth in the 1990s, yet the latter reveals more volatilities than the former and reduces the trading income. Additionally, the study indicated a negative relation between non-interest income and returns.

One defining characteristic of Vietnam's commercial banks is their increasing number, resulting from a series of banks in rural areas upgraded to joint-stock commercial banks; thus, income diversification may be highly beneficial to these. From the above analyses and prior discussions on the diversification, profitability, and the specific case of Vietnam, we suggest the following hypothesis.

H1: The higher level of income diversification is associated with higher returns.

\subsection{Diversification and bank risk}

With respect to the risk to diversification of banking activities and from a conventional wisdom in the finance and banking industry, non-interest income that comes from service charges often proves more stable than interest income; hence, bank risk reduction can be achieved (DeYoung \& Roland, 2001). Chiorazzo et al. (2008) and Lee et al. (2014) argued for the likelihood of reduction in bank risk via income diversification.

All the same, the opposite view has been supported in many studies, which imply that income diversification may entail increased risk among commercial banks. The reason is such that loan-based income may be stable over time because customers are afraid of a shift in credit relationship (switching and information costs are required in the event of changes in lending relationship), while non-interest income is likely to become highly volatile because banks can easily shift to lending activities. Moreover, banks expand their activities for non-interest income, and this will involve increased fixed costs, leading to increased operating leverage and higher risk (DeYoung \& Roland, 2001). This argument is further supported in many empirical studies, such as Lepetit et al. (2008) and Baele et al. (2007). 
In the past many Vietnamese commercial banks attempted to diversify income sources through risky investments in real estate and stocks or through the establishment of a series of subsidiaries and associate companies. Expansion into new areas involving high risk without sufficient experience leads to more serious risk posed to these banks and reduced risk-adjusted returns. Thus, another hypothesis can be formulated on the ground of distinctive commercial banks in Vietnam and the above discussion.

H2: The higher level of income diversification is associated with higher risk, but lower risk-adjusted returns.

\section{Data and methodology}

\subsection{Research data}

The data was collected from the audited, annually reported, and prospectus- and noteincluded financial statements of 37 Vietnam's commercial banks in 2006-2013, which consist of one state bank ${ }^{1}$ and 36 joint-stock commercial banks. The dataset does not include the Vietnam Bank for Social Policies, the Vietnam Development Bank, five $100 \%$ foreign-owned banks, four joint-venture banks, one cooperative bank (formerly the Central People's Credit Fund), and five merged banks ${ }^{2}$. We perform a regression using unbalanced panel data.

\subsection{Diversification measurement}

In this study we examine income diversification based on bank income structure, including interest and non-interest income. If a bank's revenue comes only from netinterest income, then it is characterized as being concentrated, whereas that from both interest and non-interest sources is considered to be diversified, and the diversification of two main bank income sources is measured by HHI_REV, an indicator of changes in bank income (Elsas et al., 2010; Gurbuz et al., 2013; Sanya \& Wolfe, 2011; TrujilloPonce, 2013), calculated as follows:

$$
H H I_{-} R E V=\left(\frac{N O N}{N E T O P}\right)^{2}+\left(\frac{N E T}{N E T O P}\right)^{2}
$$

where NON represents non-interest income, measured by total income from fees and commissions from service streams, foreign exchange and gold trading, trading and 
investment stock transactions, capital raising, and share purchases; NET is net interest income; and NETOP is net operating income, estimated by a sum of non-interest income and net interest income $(\mathrm{NETOP}=\mathrm{NON}$ and NET).

Modelling the impact

Similar to Sanya \& Wolfe (2011), we focus on profitability and risk with respect to commercial banks' income diversification through the equations presented as follows:

Profitability $_{i t}=\alpha_{0}+\alpha_{1} * H H I_{R E V} i t+\alpha_{2} * L_{A_{i t}}+\alpha_{3} * S I Z E_{i t}$

$+\alpha_{4} * A S S E T \_G R O_{i t}+\alpha_{5} * D P S \_T A_{i t}+\alpha_{6} * G L_{-} G R O_{i t}+\varepsilon_{i t}$

Risk_Adjusted_Profitability ${ }_{i t}$

$$
\begin{aligned}
& =\gamma_{0}+\gamma_{1} * H H I_{-} R E V_{i t}+\gamma_{2} * L_{-} A_{i t}+\gamma_{3} * S I Z E_{i t}+\gamma_{4} \\
& * A S S E T \_G R O_{i t}+\gamma_{5} * D P S_{-} T A_{i t}+\gamma_{6} * G L_{-} G R O_{i t}+\varepsilon_{i t}
\end{aligned}
$$

where:

Profitabilityit: an indicator of bank profits, measured by ROAA and ROAE at the end of year $t$ of bank $i$ - ROAA is the ratio of return to total average assets of the bank, representing profitability or income generating effect of bank assets and calculated by the aggregate profit before tax as a ratio to average total assets of the two consecutive years at the end of the financial year (Chiorazzo et al., 2008; Grossman, 1994; Lee et al., 2014), and ROAE, estimated by after-tax income as a ratio to average equity of the two consecutive years at the end of the financial year (Lee et al., 2014; Trujillo-Ponce, 2013).

Risk_Ajusted_Profitabilityit: an indicator of bank risk, measured by RAROA, RAROE, and Z_SCORE of bank $i$ in year $t$ and thus computed as follows:

$$
\begin{aligned}
\text { RAROA }_{\text {it }} & =\frac{\text { ROA }_{\text {it }}}{6_{\text {ROAit }}} \\
\text { RAROE }_{\text {it }} & =\frac{\text { ROE }_{\text {it }}}{6_{\text {ROEit }}} \\
Z_{-} S_{C O R E} & =\frac{\text { ROA }_{\text {it }}+E_{-} A_{i t}}{6_{\text {ROAit }}}
\end{aligned}
$$

L_A $\mathrm{A}_{\mathrm{it}}$ : an indicator of loans, estimated using total loans as a ratio to total assets of bank $i$ in year $t$ (DeYoung \& Roland, 2001; DeYoung \& Rice, 2004; Stiroh, 2004b; Stiroh \& Rumble, 2006). 
SIZE $_{\mathrm{it}}$ : size of bank $i$ in year $t$, calculated by total assets in natural logarithm (in million VND) at the end of the financial year (Acharya et al., 2006; Gurbuz et al., 2013; Lee et al., 2014; Sanya \& Wolfe, 2011).

ASSET_GRO $\mathrm{it}_{\mathrm{it}}$ an indicator of asset growth of bank $i$ in year $t$, measured by the ratio of growth in total assets in the current year to that in the previous year; using ASSET_GROW in the model is to control for the effect of rapid expansion on the profitability as well as bankruptcy risk of the bank (Lee et al., 2014; Sanya \& Wolfe, 2011).

DPS_TA $\mathrm{it}_{\mathrm{i}}$ : a variable to reflect the deposit level of bank $i$ in year $t$, measured by the ratio of total deposits to total assets (Lei \& Song, 2013; Lepetit et al., 2008).

$\mathrm{GL}_{-} \mathrm{GRO}_{\mathrm{it}}$ : the level of gross loan growth of bank $i$ in year $t$, calculated by loan growth in the current year compared to that in the previous year $(\%)$

$\varepsilon_{\mathrm{it}}$ : unobserved error term of bank $i$ in year $t$.

\section{Table 1}

Description of variables included in the analysis

\begin{tabular}{|c|c|c|}
\hline Variable & Description & Measured by \\
\hline \multicolumn{3}{|l|}{ Return } \\
\hline ROAA & Return on average assets (\%) & $\begin{array}{l}\text { Profit before tax } /[(\text { total assets in year } t \\
+ \text { total assets in year } t-1) / 2]\end{array}$ \\
\hline ROAE & Return on average equity (\%) & $\begin{array}{l}\text { Profit after } \operatorname{tax} /[\text { (equity in year } t+ \\
\text { equity in year } t-1) / 2]\end{array}$ \\
\hline \multicolumn{3}{|c|}{ Risk-adjusted return } \\
\hline RAROA & Risk-adjusted ROA (\%) & $\mathrm{ROA} / \sigma_{\mathrm{ROA}}$ \\
\hline RAROE & Risk-adjusted ROE (\%) & $\mathrm{ROE} / \sigma_{\mathrm{ROE}}$ \\
\hline Z_SCORE & & $\left(\mathrm{ROA}+\mathrm{E} \_\mathrm{A}\right) / \sigma_{\mathrm{ROA}}$ \\
\hline
\end{tabular}




\begin{tabular}{lll}
\hline \multicolumn{1}{c}{ Variable } & \multicolumn{1}{c}{ Description } & \multicolumn{1}{c}{ Measured by } \\
\hline Income diversification & & \\
HHI_REV & Diversification of revenue & $(\text { NON/NETOP })^{2}+(\mathrm{NET} / \mathrm{NETOP})^{2}$ \\
\hline Control variables & & \\
L_A & Loan/asset ratio & Total loans/total assets \\
SIZE & Bank size & Ln(total assets) \\
ASSET_GRO & Rate of asset growth $(\%)$ & $\begin{array}{l}\text { (Total assets in year } t \text { - total assets in } \\
\text { year } t-1) / \text { total assets in year } t-1\end{array}$ \\
DPS_TA & Deposit rate & Total deposits/total assets \\
GL_GRO & Rate of loan growth $(\%)$ & (Loan in year $t$ - loan in year $t-1) /$ loan \\
& & in year $t-1$ \\
\hline
\end{tabular}

\subsection{Estimation methods}

We adopt the common techniques in panel data regression. First, we use the Hausman test to decide between fixed and random effects estimators. The test results show that the calculated chi-square value for the equations of ROAA and ROAE is less than 5\%; hence, we employ the fixed effects estimator for regression of these dependent variables. Given the equations of RAROA, RAROE, and Z_SCORE, the chi-square value is higher than $5 \%$, so the random effects estimator can be applied to regression of these three variables. Additionnaly, the use of GMM estimator, an optimal technique to handle endogeneity, is to improve reliability of the research methods.

\section{Results and discussion}

Table 2 summarizes the statistical description of the variables employed in this study.

\section{Table 2}

Statistical description of variables

\begin{tabular}{|c|c|c|c|c|}
\hline Variable & Mean & Max & Min & Std. dev. \\
\hline \multicolumn{5}{|l|}{ Return } \\
\hline ROAA & 0.0176 & 0.0716 & 0.0002 & 0.0122 \\
\hline
\end{tabular}




\begin{tabular}{lcccc}
\hline \multicolumn{1}{c}{ Variable } & Mean & Max & Min & Std. dev. \\
\hline ROAE & 0.1154 & 0.4449 & 0.0007 & 0.0705 \\
Risk-adjusted return & & & & \\
RAROA & 2.8556 & 17.4368 & 0.0206 & 2.6080 \\
RAROE & 2.7429 & 10.7717 & 0.0158 & 1.9308 \\
Z_SCORE & 27.5960 & 226.7730 & 5.4816 & 27.5132 \\
\hline $\begin{array}{l}\text { Income } \\
\text { HHI_REV }\end{array}$ & 0.7608 & 2.8541 & 0.5002 & 0.2574 \\
\hline Bank characteristics & & & & \\
L_A & 0.5153 & 0.9442 & 0.1138 & 0.1518 \\
SIZE & 17.2490 & 20.1723 & 13.0115 & 1.4664 \\
ASSET_GRO & 0.6170 & 12.6611 & -0.4069 & 1.2180 \\
DPS_TA & 0.8340 & 0.9477 & 0.3628 & 0.0936 \\
GL_GRO & 0.5709 & 11.3173 & -0.4076 & 1.1830 \\
\hline
\end{tabular}

Table 3 presents correlation coefficient matrix of the variables in the model. The correlation coefficients are used for testing the presence of multicollinearity among the variables. The results indicate that no pairs produce the absolute value of larger than 0.8 ; thus, we can conclude that there is no strong possibility that the multicollinearity exists due to rather small values of most of the correlation coefficients.

\section{Table 3}

Correlation coefficient matrix of variables

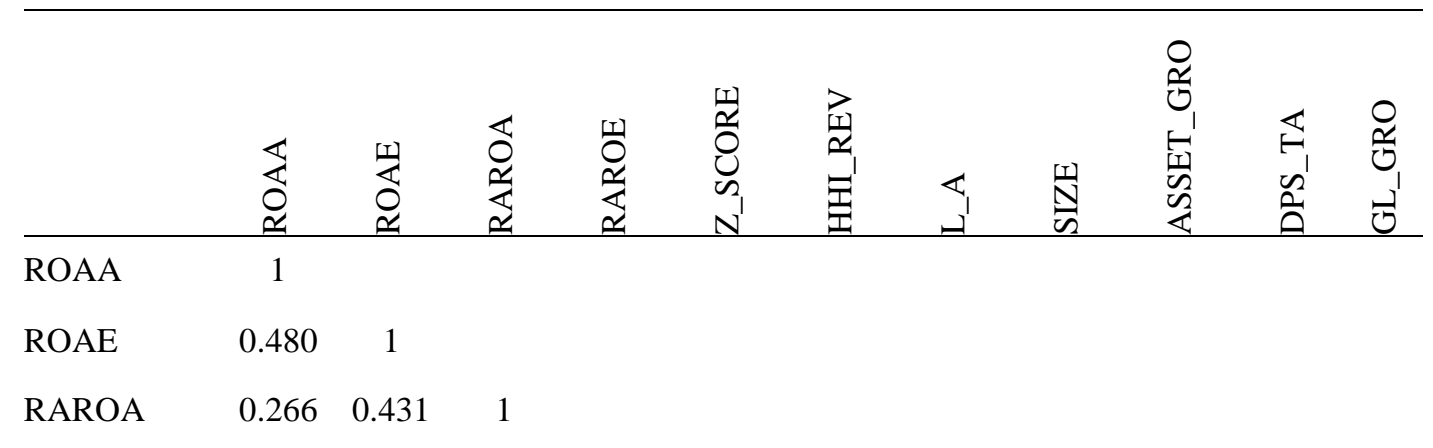




$\begin{array}{lccccccccccc}\text { RAROE } & 0.258 & 0.558 & 0.843 & 1 & & & & & & \\ \text { Z_SCORE } & 0.072 & -0.043 & 0.781 & 0.485 & 1 & & & & & \\ \text { HHI_REV } & -0.139 & -0.236 & -0.147 & -0.158 & -0.055 & 1 & & & & \\ \text { L_A } & 0.103 & -0.026 & 0.022 & 0.033 & 0.004 & -0.013 & 1 & & & \\ \text { SIZE } & -0.465 & 0.285 & 0.121 & 0.261 & -0.116 & -0.113 & -0.060 & 1 & & \\ \text { ASSET_GRO } & 0.287 & 0.089 & 0.006 & 0.016 & 0.020 & -0.119 & -0.223 & -0.291 & 1 & \\ \text { DPS_TA } & -0.542 & 0.210 & 0.051 & 0.206 & -0.159 & -0.139 & -0.119 & 0.648 & -0.116 & 1 \\ \text { GL_GRO } & 0.229 & 0.080 & 0.006 & 0.034 & 0.005 & -0.142 & -0.117 & -0.245 & 0.751 & -0.085 & 1\end{array}$

Table 4 shows the regression results with fixed effects and GMM estimators for panel data; two of the dependent variables that proxy for bank returns are ROAA and ROAE. The coefficient of income diversification, as indicated, is negative and statistically significant at $1 \%$ level. Hence, the diversification is found to increase profits, and we can accept the hypothesis that the higher level of the income diversification leads to higher returns (H1).

\section{Table 4}

Estimated results with ROAA and ROAE as two dependent variables

\begin{tabular}{|c|c|c|c|c|c|c|c|c|}
\hline \multirow{3}{*}{ Variable } & \multicolumn{4}{|c|}{ ROAA } & \multicolumn{4}{|c|}{ ROAE } \\
\hline & \multicolumn{2}{|c|}{ Fixed effects } & \multicolumn{2}{|c|}{ GMM } & \multicolumn{2}{|c|}{ Fixed effects } & \multicolumn{2}{|c|}{ GMM } \\
\hline & Coef. & p-value & Coef. & p-value & Coef. & p-value & Coef. & p-value \\
\hline $\mathrm{C}$ & 0.139 & 0.000 & & & 0.470 & 0.000 & & \\
\hline $\operatorname{Lag}(-1)$ & & & 0.366 & 0.000 & & & 0.649 & 0.000 \\
\hline HHI_REV & $\begin{array}{c}- \\
0.010\end{array}$ & 0.000 & -0.019 & 0.000 & -0.038 & 0.023 & -0.057 & 0.000 \\
\hline L_A & $\begin{array}{c}- \\
0.003\end{array}$ & 0.620 & -0.010 & 0.021 & -0.108 & 0.012 & 0.027 & 0.537 \\
\hline SIZE & $\begin{array}{c}- \\
0.005\end{array}$ & 0.000 & -0.001 & 0.130 & -0.025 & 0.000 & 0.018 & 0.000 \\
\hline ASSET_GRO & 0.001 & 0.122 & -0.003 & 0.000 & 0.001 & 0.874 & 0.014 & 0.144 \\
\hline
\end{tabular}




\begin{tabular}{|c|c|c|c|c|c|c|c|c|}
\hline \multirow{3}{*}{ Variable } & \multicolumn{4}{|c|}{ ROAA } & \multicolumn{4}{|c|}{ ROAE } \\
\hline & \multicolumn{2}{|c|}{ Fixed effects } & \multicolumn{2}{|c|}{ GMM } & \multicolumn{2}{|c|}{ Fixed effects } & \multicolumn{2}{|c|}{ GMM } \\
\hline & Coef. & p-value & Coef. & p-value & Coef. & p-value & Coef. & p-value \\
\hline DPS_TA & $\begin{array}{c}- \\
0.028\end{array}$ & 0.009 & -0.017 & 0.047 & 0.180 & 0.006 & -0.072 & 0.550 \\
\hline GL_GRO & 0.001 & 0.510 & 0.007 & 0.000 & 0.007 & 0.154 & 0.028 & 0.000 \\
\hline $\mathrm{R}^{2}$ & 0.617 & & & & 0.576 & & & \\
\hline Adjusted $\mathrm{R}^{2}$ & 0.536 & & & & 0.486 & & & \\
\hline $\begin{array}{l}\text { Prob } \\
\text { (F-statistic) }\end{array}$ & 0.000 & & & & 0.000 & & & \\
\hline J-statistic & & & 28.121 & & & & 24.061 & \\
\hline $\begin{array}{l}\text { Prob(j- } \\
\text { statistic) }\end{array}$ & & & 0.107 & & & & 0.240 & \\
\hline $\mathrm{AR}(1)$ & & & 0.000 & & & & 0.004 & \\
\hline $\operatorname{AR}(2)$ & & & 0.591 & & & & 0.817 & \\
\hline
\end{tabular}

Regarding risk-adjusted return, Table 5 demonstrates the results of regression using random effects and GMM estimators with such two dependent variables as RAROA and RAROE. Also evidenced by the table, the regression coefficients of HHI_REV for the two cases of RAROA and RAROE are negative and statistically significant at $1 \%$ level, implying that the higher level of income diversification results in higher risk yet lower risk-adjusted profits.

\section{Table 5}

Estimated results with RAROA and RAROE as two dependent variables

\begin{tabular}{lcccccccc}
\hline & \multicolumn{3}{c}{ RAROA } & \multicolumn{4}{c}{ RAROE } \\
\cline { 2 - 8 } Variable & \multicolumn{2}{c}{ Random effects } & \multicolumn{2}{c}{ GMM } & \multicolumn{2}{c}{ Random effects } & \multicolumn{2}{c}{ GMM } \\
\cline { 2 - 8 } & Coef. & p-value & Coef. & p-value & Coef. & p-value & Coef. & p-value \\
\hline $\mathrm{C}$ & 12.517 & 0.000 & & & 5.206 & 0.007 & \\
$\operatorname{Lag}(-1)$ & & & 0.166 & 0.040 & & & 0.343 & 0.000 \\
\hline
\end{tabular}




\begin{tabular}{|c|c|c|c|c|c|c|c|c|}
\hline \multirow{3}{*}{ Variable } & \multicolumn{4}{|c|}{ RAROA } & \multicolumn{4}{|c|}{ RAROE } \\
\hline & \multicolumn{2}{|c|}{ Random effects } & \multicolumn{2}{|c|}{ GMM } & \multicolumn{2}{|c|}{ Random effects } & \multicolumn{2}{|c|}{ GMM } \\
\hline & Coef. & p-value & Coef. & p-value & Coef. & p-value & Coef. & p-value \\
\hline HHI_REV & -0.704 & 0.011 & -1.171 & 0.000 & -0.732 & 0.017 & -1.243 & 0.000 \\
\hline L_A & -1.033 & 0.140 & -3.280 & 0.001 & -1.784 & 0.024 & -2.110 & 0.125 \\
\hline SIZE & -0.403 & 0.000 & -0.138 & 0.254 & -0.242 & 0.022 & 0.026 & 0.817 \\
\hline ASSET_GRO & -0.003 & 0.975 & -0.288 & 0.032 & -0.062 & 0.498 & -0.012 & 0.964 \\
\hline DPS_TA & -1.856 & 0.088 & -2.036 & 0.213 & 3.734 & 0.002 & 3.131 & 0.109 \\
\hline GL_GRO & 0.078 & 0.358 & 0.726 & 0.000 & 0.184 & 0.051 & 0.533 & 0.039 \\
\hline $\mathrm{R}^{2}$ & 0.181 & & & & 0.805 & & & \\
\hline Adjusted $\mathrm{R}^{2}$ & 0.160 & & & & 0.764 & & & \\
\hline $\begin{array}{l}\text { Prob } \\
\text { (F-statistic) }\end{array}$ & 0.000 & & & & 0.000 & & & \\
\hline J-statistic & & & 28.115 & & & & 25.497 & \\
\hline $\begin{array}{l}\text { Prob } \\
\text { (j-statistic) }\end{array}$ & & & 0.107 & & & & 0.183 & \\
\hline $\mathrm{AR}(1)$ & & & 0.000 & & & & 0.000 & \\
\hline $\operatorname{AR}(2)$ & & & 0.591 & & & & 0.167 & \\
\hline
\end{tabular}

The results of regression using fixed effects and GMM estimators with Z_SCORE as a dependent variable and a proxy for risk-adjusted return (Table 6) indicate that the coefficients of income diversification are negative and not statistically significant for the fixed effects estimator, yet are positive and significant at $10 \%$ level for the GMM estimator. Accordingly, in terms of Z_SCORE, the results are quite contradictory for the income diversification in its relation to bank profitability and risk. 


\section{Table 6}

Estimated results with Z_SCORE as a dependent variable

\begin{tabular}{lcccc}
\hline \multirow{2}{*}{ Variable } & \multicolumn{2}{c}{ Fixed effects } & \multicolumn{2}{c}{ GMM } \\
\cline { 2 - 5 } & Coef. & p-value & Coef. & p-value \\
\hline C & 136.217 & 0.000 & & \\
Z_SCORE(-1) & & & -0.156 & 0.000 \\
\hline HHI_REV & -0.544 & 0.761 & 1.734 & 0.070 \\
\hline L_A & 3.463 & 0.453 & 22.841 & 0.000 \\
SIZE & -1.759 & 0.005 & -2.160 & 0.013 \\
ASSET_GRO & 0.922 & 0.087 & 4.657 & 0.000 \\
DPS_TA & -96.501 & 0.000 & -100.114 & 0.000 \\
GL_GRO & -1.080 & 0.052 & -4.793 & 0.000 \\
\hline R ${ }^{2}$ & 0.956 & & & \\
Adjusted R & & & & \\
Prob(F-statistic) & 0.947 & & & \\
J-statistic & 0.000 & & 0.492 & \\
Prob(j-statistic) & & & 0.095 & \\
AR(1) & & & 0.328 & \\
AR(2) & & & & \\
\hline
\end{tabular}

Nevertheless, most of the findings obtained from Table 5 allow us to accept the hypothesis that the higher level of income diversification is associated with higher risk, but lower risk-adjusted returns $(\mathrm{H} 2)$.

\section{Conclusion and implications}

\subsection{Conclusion}

One of the issues that captures scant attention of different individuals, such as bank managers or policy makers, is the diversification of banking activities. As a contribution to the theoretical and practical debates, in this study we have considered the issue from 
the perspectives of bank profitability and risk. Using the panel data for the 2006-2013 period in addition to other common regression techniques, we find that Vietnam's commercial banks, with expansion into diversified non-interest generating activities, do earn higher returns. Still, if bank risk is taken into account, the income diversification causes a lower level of risk-adjusted returns, whereas the banks face greater risk than those benefiting from traditional income sources.

\subsection{Implications}

This study also proposes several implications for bank managers and policy makers in their orienting the national commercial banks' performance.

Firstly, given bank managers, empirical evidence has been provided of the relations existing among profitability, risk, and income diversification, based on which effective strategies can be devised. It is suggested that the diversified bank performance leads to lower risk-adjusted profits and higher profits if risk is and is not considered respectively, which is significant to banks' diverfication practices. During the stated process the factor of risk should be addressed for the managers' adopting coherent business strategies aimed at the optimal income generation and reduced bank risk.

Secondly, as indicated by the findings, banks during diversification facing the challenge of high risk should focus on traditional income generation activities. Implementing such, on the one hand, proves that the banks function properly, and on the other hand, clearly defines the role of commercial banking system in the economy. Moreover, bank managers should improve their governance performance, and modern technologies are to be adopted to increase profits and reduce risk for the commercial banks. Particularly, small-scale banks should enhance the quality of capital mobilization and traditional lending activities, in which it is important to focus on a specific group of customers from whom they gain advantage, rather than the diversification into other potentially riskier services.

Thirdly, a few implications can be suggested for policy makers in various banking regulatory agencies. Since no increase in bank returns is reflected when risk is involved, this implies that they are supposed to adopt measures that limit bank expansion into nonbanking activities, especially into high-risk investments as in real estate or stock market as well as others in which no experience and advantages can be gained. More importantly, policy makers need to have strict policies to restrict the use of bank deposits in the risky investments as were mentioned 


\section{Notes}

${ }^{1}$ The state commercial bank is Vietnam Bank for Agriculture and Rural Development (source: SBV).

${ }^{2} 100 \%$ foreign-owned banks are HSBC, Standard Chartered, Shinhan Vietnam, ANZVL, and Hong Leong; joint-venture banks are VID Public Bank, Indovina Bank Limited, Vinasiam Bank, and Vietnam-Russia Joint Venture Bank; meged banks include Vietnam Tinnghiabank.

\section{References}

Acharya, V. V., Hasan, I., \& Saunders, A. (2006). Should banks be diversified? Evidence from individual bank loan portfolios. The Journal of Business, 79(3), 1355-1412.

Baele, L., De Jonghe, O., \& Vander Vennet, R. (2007). Does the stock market value bank diversification? Journal of Banking \& Finance, 31(7), 1999-2023.

Carlson, M. (2004). Are branch banks better survivors? Evidence from the depression era. Economic Inquiry, 42(1), 111-126.

Chiorazzo, V., Milani, C., \& Salvini, F. (2008). Income diversification and bank performance: Evidence from Italian banks. Journal of Financial Services Research, 33(3), 181-203.

DeYoung, R., \& Rice, T. (2004). Noninterest income and financial performance at US commercial banks. Financial Review, 39(1), 101-127.

DeYoung, R., \& Roland, K. P. (2001). Product mix and earnings volatility at commercial banks: Evidence from a degree of total leverage model. Journal of Financial Intermediation, 10(1), 5484.

Elsas, R., Hackethal, A., \& Holzhäuser, M. (2010). The anatomy of bank diversification. Journal of Banking \& Finance, 34(6), 1274-1287.

Grossman, R. S. (1994). The shoe that didn't drop: Explaining banking stability during the great depression. The Journal of Economic History, 54(03), 654-682.

Gurbuz, A. O., Yanik, S., \& Ayturk, Y. (2013). Income diversification and bank performance: Evidence from Turkish banking sector. Journal of BRSA Banking and Financial Markets, 7(1), 929.

Landskroner, Y., Ruthenberg, D., \& Zaken, D. (2005). Diversification and performance in banking: The Israeli case. Journal of Financial Services Research, 27(1), 27-49.

Lee, C. C., Hsieh, M. F., \& Yang, S. J. (2014). The relationship between revenue diversification and bank performance: Do financial structures and financial reforms matter? Japan and the World Economy, 29, 18-35.

Lei, A. C., \& Song, Z. (2013). Liquidity creation and bank capital structure in China. Global Finance Journal, 24(3), 188-202. 
Lepetit, L., Nys, E., Rous, P., \& Tarazi, A. (2008). Bank income structure and risk: An empirical analysis of European banks. Journal of Banking \& Finance, 32(8), 1452-1467.

Niu, J. (2012). An empirical analysis of the relation between bank charter value and risk taking. The Quarterly Review of Economics and Finance, 52(3), 298-304.

Pennathur, A. K., Subrahmanyam, V., \& Vishwasrao, S. (2012). Income diversification and risk: Does ownership matter? An empirical examination of Indian banks. Journal of Banking \& Finance, 36(8), 2203-2215.

Sanya, S., \& Wolfe, S. (2011). Can banks in emerging economies benefit from revenue diversification? Journal of Financial Services Research, 40(1-2), 79-101.

Smith, R., Staikouras, C., \& Wood, G. (2003). Non-interest income and total income stability (Working Paper No. 198). London, UK: Bank of England.

Stiroh, K. J. (2004a). Diversification in banking: Is noninterest income the answer? Journal of Money, Credit and Banking, 36(5), 853-882.

Stiroh, K. J. (2004b). Do community banks benefit from diversification? Journal of Financial Services Research, 25(2-3), 135-160.

Stiroh, K. J. (2006). A portfolio view of banking with interest and noninterest activities. Journal of Money, Credit and Banking, 38(5), 1351-1361.

Stiroh, K. J., \& Rumble, A. (2006). The dark side of diversification: The case of US financial holding companies. Journal of Banking \& Finance, 30(8), 2131-2161.

Trujillo-Ponce, A. (2013). What determines the profitability of banks? Evidence from Spain. Accounting \& Finance, 53(2), 561-586.

Wagner, W. (2010). Diversification at financial institutions and systemic crises. Journal of Financial Intermediation, 19(3), 373-386. 